\title{
Analisis Strategi Pemasaran Restoran Menghadapi Masa Pandemi Covid 19 Di Kota Pagar Alam
}

\author{
Pelliyezer Karo Karo ${ }^{* *}$, Samuel Hamonangan \\ Politeknik Pariwisata Palembang, Indonesia \\ https://orcid.org/0000-0002-2462-5297 \\ Email Corresponding Author: pelliyezer@poltekpar-palembang.ac.id
}

\begin{abstract}
ABSTRAK
Penelitian ini untuk mengidentifikasi alternatif strategi pengembangan yang dapat diimplementasikan oleh usaha restoran di Kota Pagar Alam dalam menghadapi situasi pandemi covid 19. Teknik analisis menggunakan matriks IFE, EFE, IE, SWOT dan QSPM terhadap data primer yang diperoleh dari 70 responden konsumen dan 5 responden pengelola restoran. Hasil akhir penelitian menunjukkan penggunaan strategi terpilih adalah pembangunan model $e$ commerce melalui kolaborasi platform digital yang bertujuan untuk memperkecil gap usaha dengan target pasar yang mengalami pergeseran selama masa pandemi. Strategi terpilih melalui rangkaian analisis dengan hasil akhir adalah nilai TAS sebesar 5,3777. Implementasi strategi dipastikan akan berdampak pada pola pengelolaan restoran baik berkaitan langsung dengan produk, pelayanan maupun aspek keuangan.
\end{abstract}

Kata kunci: Strategi Pemasaran, Restoran Pagar Alam, Analisis QSPM

\section{PENDAHULUAN}

Status sebagai pandemi dari kondisi penyebaran corona virus desease atau disingkat dengan Covid-19 ditetapkan oleh Organisasi Kesehatan Dunia atau WHO mulai tanggal 11 Maret 2020. Status tersebut disematkan karena sejak bermula pada Desember 2019 lalu di Wuhan, China, Covid-19 telah menyebar secara global ke seluruh belahan benua dan menginfeksi manusia dengan total 59.401.413 kasus dengan 1.401 .106 orang meninggal dunia (news.google.com, diakses pada 25 November 2020).

Pandemi Covid-19 mendorong ekonomi ke dalam great lockdown, membantu menahan penyebaran virus dan menyelamatkan hidup, tetapi juga memicu pelambatan ekonomi tidak hanya di Indonesia tetapi juga dunia. Seluruh sendi ekonomi terdampak, baik usaha barang maupun jasa. Pemulihan bisnis dapat berlangsung lama dan sangat lambat. Industri layanan makanan minuman dan perhotelan telah menjadi salah satu bisnis yang terparah terkena dampak pandemi ini, melalui gangguan besar di sektor konsumen. Pemilik restoran harus berusaha mengelola dengan melihat model bisnis baru dan belajar beradaptasi dengan cara baru dalam melakukan sesuatu agar mampu bertahan dalam bisnis. Hasil survei Badan Pusat Statistik (BPS) mencatat 82,85\% perusahaan terdampak oleh pandemi virus corona Covid-19. Berdasarkan sektornya, usaha akomodasi dan makan/minum merupakan yang paling banyak mengalami penurunan pendapatan, yakni 92,47\% per 15 September 2020 (Katadata.co.id, diakses pada 01 November 2020).

Dampak tersebut juga dialami sektor akomodasi dan makan minum Provinsi Sumatera Selatan yang mengalami pertumbuhan year on year hanya sebesar 7,56\% pada Semester I 2020 sesuai data BPS Sumsel publikasi Agutus 2020. Publikasi BPS pada katalog Indikator Ekonomi pada Agustus 2020, mencatat sektor penyediaan makan minum mengalami inflasi sebesar $0,13 \%$, tertinggi ketiga dari sembilan sektor. Hal ini mengindikasikan bahwa sektor makan 
minum, baik secara nasional, regional hingga lokal mengalami dampak yang cukup signifikan akibat situasi pandemi saat ini.

Kota Pagar Alam merupakan salah satu dari empat kota atau total 17 kabupaten/kota di wilayah administratif Provinsi Sumatera Selatan. Pagar Alam kaya akan potensi wisata mulai dari lokasi purbakala, situs menhir hingga 33 air terjun. Potensi wisata ini juga menjadi peluang bagi pengembangan sektor penyedia makanan minuman seperti restoran, baik diperuntukkan bagi konsumen lokal maupun bagi wisatawan. Pada masa pandemi covidi 19 tahun 2020 ini, pariwisata merupakan salah satu sektor sangat terdampak, terlihat dari jumlah wisatawan mancanegara mulai April hingga September 2020 menyentuh batas terendah nol, sesuai publikasi Berita Resmi Statistik BPS Sumatera Selatan pada 02 November 2020. Hal tersebut berpengaruh langsung terhadap keberlangsungan restoran di seluruh wilayah destinasi wisata, tidak terkecuali di Kota Pagar Alam. Pagar Alam mencatatkan terdapat 26 rumah makan/ restoran terbagi atas 8 di Kecamatan Pagar Alam Selatan dan 18 di Kecamatan Pagar Alam Utara.

Setiap usaha atau bisnis di era pandemi harus berusaha bersikap inovatif dan kreatif agar mampu bertahan, termasuk usaha restoran di Pagar Alam. Dalam situasi dan kondisi saat ini, mutlak konsumen restoran di Pagar Alam hanya merupakan wisatawan nusantara atau bahkan konsumen lokal. Dengan begitu banyaknya batasan faktor alam, kesehatan, pangsa pasar, pola perilaku konsumen yang sedang terjadi, dibutuhkan strategi yang mampu berjalan beriringan dan berdampingan, dengan harapan restoran di Pagar Alam mampu bertahan atau bahkan mampu memberikan kontribusi hingga 4 persen terhadap PDRB Kota Pagar Alam. Pola strategi yang dibangun dalam penelitian ini menggunakan Matriks SWOT (Strength Weakness Opputunity Threat) dan QSPM (Quantitative Strategic Planning Management). Melalui penelitian ini, diharapkan usaha restoran di Kota Pagar Alam secara khusus, dapat memiliki peta panduan dan alternatif strategi pemasaran agar menjadi lebih fokus dalam mengembangkan bisnisnya dari sudut pandang internal dan eksternal sehingga mampu bertahan menghadapi pandemi covid 19.

\section{METODOLOGI PENELITIAN}

Jenis penelitian ini adalah observasional dengan metode survey yang bersifat deskriptif dan analitik dengan menggunakan data hasil survei dikumpulkan dengan teknik wawancara schedule questionnaire atau interview guide. Pendekatan penelitian yang digunakan adalah pendekatan kualitatif dan pendekatan kuantitatif. Pendekatan kualitatif menekankan pada pembangunan naratif atas fenomena akibat pandemi covid 19 bertujuan menghasilkan alternatif strategi pemasaran yang diteliti sedangkan penelitian kuantitatif menekankan pada penelitian numerik berupa identifikasi posisi pasar.

Populasi pada penelitian ini adalah konsumen yang sedang menggunakan layanan jasa makan minum dari restoran di di Kota Pagar Alam, selama proses penelitian ini berlangsung, dengan beberapa asumsi tertentu. Hasil observasi penelitian menunjukkan terdapat 14 usaha restoran dengan karakteristik serupa, 5 restoran dengan tingkat respon tertinggi ditetapkan menjadi sumber data primer.

Berdasarkan publikasi data BPS Kota Pagar Alam nomor katalog 9302021.1673 pada Februari 2020, distribusi persentase sektor penyediaan akomodasi dan makan minum berada di angka 3,88 persen atas PDRB Kota Pagar Alam. Angka tersebut diasumsikan sebagai perwakilan prevalensi outcome dari jumlah konsumen. Hasil perhitungan sampel menjadi stratum yang terproporsi bagi setiap lokus restoran. Metode pengambilan sampel yang digunakan adalah dengan menggunakan nonprobability sampling dengan teknik sampling adalah accidental sampling. 
Dikarenakan besar populasi tidak diketahui secara langsung, maka penentuan jumlah sample dalam penelitian ini menggunakan pendekatan rumus Lemeshow berikut:

$$
n \geq \frac{Z_{\propto / 2}^{2} P Q}{L^{2}}
$$

Sehingga berdasarkan perhitungan diperoleh nilai sebesar 14 dan dengan demikian jumlah sampel dalam penelitian ini sebanyak 70 orang konsumen ditambah 5 orang pemilik/pengelola restoran dengan total menjadi 75 responden.

\section{Definisi Operasional Variabel}

Adapun definisi operasional dari 36 indikator yang diukur atau diobservasi dengan skala ukur rating scale mencakup:

1. Faktor Internal

Variabel dalam faktor internal dikembangkan pada indikator bauran pemasaran, meliputi 22 indikator:

a. Produk terbagi atas variasi menu, rasa, brand, kualitas produk dan kepercayaan produk.

b. Harga terbagi atas keterjangkauan harga dan kesesuaian dengan kualitas.

c. Lokasi terbagi atas lokasi strategis dan area parkir.

d. Promosi terbagi atas penjualan online, media sosial dan promo.

e. Orang terbagi atas komunikasi pekerja, jumlah pekerja dan pengetahuan menu.

f. Proses terbagi atas kualitas pelayanan dan pengajian produk.

g. Bukti fisik terbagi atas konsep restoran, kenyamanan area, kebersihan restoran, kebersihan peralatan dan fasilitas pandemi.

2. Faktor Eksternal

Variabel dalam faktor eksternal didasarkan pada lingkungan mikro meliputi 6 indikator:

a. Pemasok terbagi atas kemudahan bahan baku dan peralihan makanan beku.

b. Pelanggan terbagi atas jumlah wisatawan dan kegemaran makanan sehat.

c. Perantara pasar terbagi atas kota wisata dan zona hijau serta lingkungan makro meliputi 8 indikator:

a. Ekonomi terbagi atas daya beli masyarakat, peralihan berdasarkan harga.

b. Sosial budaya terbagi atas kesehatan produk, kebersihan area, makanan sehat dan minat memasak.

c. Teknologi terbagi atas teknologi digital dan pasar digital.

\section{Uji Instrumen}

Untuk penelitian ini akan dilakukan uji korelasi item total yang juga disebut uji korelasi butir dengan menggunakan alat tes pengujian korelasi item total dikoreksi atau corrected item total correlation dengan menggunakan degree of freedom sebesar 28 dan tingkat signifikansi untuk uji dua arah yaitu $\alpha 0,05$. Sedangkan pengujian reliabilitas menggunakan cara one shot dengan alat tes digunakan adalah koefisien alpha cronbach pada indikasi reliabilitas memadai lebih besar atau sama dengan 0,70 . 
Tabel 1. Uji Validitas dan Reabilitas Instrumen

\begin{tabular}{lcccc}
\hline \multicolumn{1}{c}{ Butir } & Corrected Item & Status & Cronbach's Alpha & Status \\
\hline Produk: Q1 - Q5 & $.792-.869$ & Valid & $.779-.867$ & Reliable \\
Harga: Q6, Q7 & $.805-.823$ & Valid & $.824-.846$ & Reliable \\
Lokasi: Q8, Q9 & $.786-.807$ & Valid & $.822-.834$ & Reliable \\
Promosi: Q10 - Q12 & $.794-.834$ & Valid & $.819-.851$ & Reliable \\
Orang: Q13- Q15 & $.810-.844$ & Valid & $.798-.826$ & Reliable \\
Proses: Q16, Q17 & $.822-.832$ & Valid & $.803-.812$ & Reliable \\
Bukti fisik: Q18- Q22 & $.804-.823$ & Valid & $.819-.842$ & Reliable \\
Pemasok: Q23, Q24 & $.825-.830$ & Valid & $.825-.850$ & Reliable \\
Pelanggan: Q25, Q26 & $.798-.809$ & Valid & $.811-.826$ & Reliable \\
Perantara Pasar:Q27, Q28 & $.835-.844$ & Valid & $.827-.835$ & Reliable \\
Ekonomi: Q29, Q30 & $.816-.822$ & Valid & $.838-.847$ & Reliable \\
Sosial Budaya: Q31 - Q34 & $.788-.822$ & Valid & $.788-.844$ & Reliable \\
Teknologi: Q35, Q36 & $.818-.824$ & Valid & $.807-.818$ & Reliable \\
\hline
\end{tabular}

Sumber: Hasil Penelitian, 2020 (IBM SPSS Statistics 22, diolah)

Dari hasil uji instrumen pada Tabel 2. menunjukkan bahwa nilai $r_{\text {hitung }}$ dari setiap butir variabel pertanyaan $>$ nilai $r_{\text {tabel }}(0,361)$, yang artinya setiap butir variabel pertanyaan dinyatakan valid. Begitu juga dengan hasil uji reliabilitas instrumen menunjukkan bahwa baik nilai koefisien alpha cronbach secara keseluruhan $(0,823)$ maupun setiap instrumen melebihi batas minimum reliabilitas sebesar 0,7 mengindikasikan bahwa secara keseluruhan semua instrumen variabel dalam penelitian ini adalah reliabel (konsisten).

\section{Karakteristik Responden}

Berdasarkan Tabel 2. menunjukkan bahwa usia responden bervariasi pada rentang interval usia 19 tahun hingga 42 tahun. Nilai terbesar berada pada usia 20 tahun sebesar 18,6 persen dan usia 22 tahun sebesar 17,1 persen. Jika responden dibagi berdasarkan rentang usia dari kelompok generasi, maka diperoleh hasil berikut:

1. Generasi X dengan rentang kelahiran tahun 1965 hingga 1980, berarti saat ini berusia pada rentang 40-55 tahun sebesar 2,86 persen.

2. Generasi Milenial dengan rentang kelahiran tahun 1994 hingga 1981, berarti saat ini berusia pada rentang 26-39 tahun sebesar 20 persen.

3. Generasi $\mathrm{Z}$ dengan rentang kelahiran tahun 1995 hingga 2010, berarti saat ini berusia pada rentang 25 tahun dan lebih muda, sebesar 77,14 persen.

Tiga bagian usia berdasarkan generasi tersebut, menunjukkan bahwa responden penelitian merupakan konsumen restoran dengan didominasi oleh generasi $\mathrm{Z}$ dan jika diakumulasikan menjadi berkisar 97 persen lebih adalah generasi $\mathrm{Z}$ dan generasi milenial. Jika dicoba temukan irisannya, bahwa pada kedua generasi tersebut, sama-sama terdiri atas mayoritas individu yang sangat akrab dengan perkembangan teknologi, tentunya ini juga berdampak pada pola berwisata maupun pola konsumsi 
Tabel 2. Karakteristik Responden Berdasarkan Usia

Usia

\begin{tabular}{|cc|r|r|r|r|}
\hline & & Frequency & Percent & Valid Percent & $\begin{array}{c}\text { Cumulative } \\
\text { Percent }\end{array}$ \\
\hline Valid & 19 & 7 & 10.0 & 10.0 & 10.0 \\
& 20 & 13 & 18.6 & 18.6 & 28.6 \\
& 7 & 10.0 & 10.0 & 38.6 \\
& 72 & 12 & 17.1 & 17.1 & 55.7 \\
23 & 7 & 10.0 & 10.0 & 65.7 \\
24 & 3 & 4.3 & 4.3 & 70.0 \\
25 & 5 & 7.1 & 7.1 & 77.1 \\
27 & 4 & 5.7 & 5.7 & 82.9 \\
29 & 3 & 4.3 & 4.3 & 87.1 \\
31 & 4 & 5.7 & 5.7 & 92.9 \\
33 & 2 & 2.9 & 2.9 & 95.7 \\
36 & 1 & 1.4 & 1.4 & 97.1 \\
42 & 2 & 2.9 & 2.9 & 100.0 \\
& 70 & 100.0 & 100.0 & \\
\hline
\end{tabular}

Sumber: Hasil Penelitian, 2020 (IBM SPSS Statistics 22)

Hasil distribusi responden pada Tabel 3. menunjukkan bahwa responden didominasi sebesar 71,4 persen berasal dari Kota Pagar Alam itu sendiri, sedangkan selebihnya sebesar 20 persen berasal dari Kota Palembang. Hal tersebut mengindikasikan, bahwa masa pandemi covid-19 secara signifikan menurunkan jumlah pengunjung dari luar daerah Pagar Alam untuk menikmati objek wisata di Pagar Alam. Secara tidak langsung, hal ini juga memberikan informasi penting bahwa konsumen restoran didominasi oleh masyarakat sekitar yang pasti memiliki perbedaan pola konsumsi dengan para wisatawan, baik wisatawan domestik maupun mancanegara.

Tabel 3. Karakteristik Responden Berdasarkan Asal

\begin{tabular}{|ll|r|r|r|r|}
\hline & & Asal \\
\hline Valid & Kota Pagar Alam & 50 & 71.4 & 71.4 & 71.4 \\
& Kota Palembang & 14 & 20.0 & 20.0 & 91.4 \\
& Kota Lubuk Linggau & 1 & 1.4 & 1.4 & 92.9 \\
Kota Prabumulin & 1 & 1.4 & 1.4 & 94.3 \\
Kabupaten Lain di & 4 & 5.7 & 5.7 & 100.0 \\
Sumsel & 70 & 100.0 & 100.0 & \\
Total & & Percent \\
\hline
\end{tabular}

Sumber: Hasil Penelitian, 2020 (IBM SPSS Statistics 22)

Tabel 4. memberikan penguatan konsisten terhadap data sebelumnya, dimana 65,7 persen responden merupakan konsumen lokal yang juga berasal dan berdomisili di Pagar Alam. Data juga menunjukkan bahwa tidak ada kunjungan wisatawan manacanegara sedangkan kunjungan wisatawan domestik hanya berada di angka 34,3 persen, dengan kata lain usaha restoran hampir sepenuhnya bertahan dari konsumsi pribadi masyarakat sekitar. Terdapat selisih data sebesar 5,7 persen antara responden berasal dari Pagar Alam dengan responden dengan status konsumen lokal, memberi makna bahwa ada 4 orang responden berasal dari Pagar Alam tetapi berstatus wisatawan domestik, dengan kemungkinan responden tersebut bisa saja tidak berdomisili di Pagar Alam, melainkan sedang melakukan kunjungan wisata ke Pagar Alam. 
Tabel 4. Karakteristik Responden Berdasarkan Kategori

\begin{tabular}{|ll|r|r|r|r|}
\hline \multicolumn{7}{|c|}{ Kategori } \\
\hline & Frequency & Percent & Valid Percent & $\begin{array}{c}\text { Cumulative } \\
\text { Percent }\end{array}$ \\
\hline Valid & Konsumen Lokal & 46 & 65.7 & 65.7 & 65.7 \\
& Wisatawan Domestik & 24 & 34.3 & 34.3 & 100.0 \\
& Total & 70 & 100.0 & 100.0 & \\
\hline
\end{tabular}

Sumber: Hasil Penelitian, 2020 (IBM SPSS Statistics 22)

Berdasarkan Tabel 5. menunjukkan bahwa sebanyak 54,3 persen responden melakukan pembelian sebanyak 1 kali seminggu, kemudian disusul oleh pembelian 2 kali seminggu sebanyak 24,3 persen, sebesar 15,7 persen lainnya merupakan pembelian sebanyak 3 kali seminggu sedangkan selebihnya 5,7 persen adalah responden yang melakukan pembelian sebanyak 4 kali seminggu. Jika didasarkan pada pembelian berulang, maka terakumulasi bahwa terdapat 45,7 persen konsumen restoran yang melakukan pembelian kembali.

Tabel 5. Karakteristik Responden Berdasarkan Frekuensi Kunjungan

\begin{tabular}{|c|c|c|c|c|c|}
\hline \multicolumn{6}{|c|}{ Frekuensi_Kunjungan } \\
\hline & & Frequency & Percent & Valid Percent & $\begin{array}{c}\text { Cumulative } \\
\text { Percent }\end{array}$ \\
\hline \multirow[t]{5}{*}{ Valid } & 1 kali seminggu & 38 & 54.3 & 54.3 & 54.3 \\
\hline & 2 kali seminggu & 17 & 24.3 & 24.3 & 78.6 \\
\hline & 3 kali seminggu & 11 & 15.7 & 15.7 & 94.3 \\
\hline & 4 kali seminggu & 4 & 5.7 & 5.7 & 100.0 \\
\hline & Total & 70 & 100.0 & 100.0 & \\
\hline
\end{tabular}

Sumber: Hasil Penelitian, 2020 (IBM SPSS Statistics 22)

Karakteristik berikutnya ditinjau berdasarkan rata-rata besaran dana yang dihabiskan oleh responden dalam melakukan transaksi di restoran. Tabel 7. menunjukkan bahwa sebanyak 44,3 persen responden mengeluarkan biaya kurang dari lima puluh ribu rupiah dalam setiap satu kali transaksi, sedangkan responden yang mengeluarkan biaya berkisar antara lima puluh ribu rupiah hingga seratus ribu rupiah per transaksi, sebesar 37,1 persen. Secara tidak langsung mengindikasikan bahwa dominan sebanyak 81,4 persen konsumen akan melakukan pembelian dengan jumlah maksimum biaya sebesar seratus ribu rupiah untuk satu kali transaksi.

Tabel 6. Karakteristik Responden Berdasarkan Rerata Pengeluaran

\begin{tabular}{|c|c|c|c|c|c|}
\hline \multicolumn{6}{|c|}{ Rerata_Konsumsi } \\
\hline & & Frequency & Percent & Valid Percent & $\begin{array}{l}\text { Cumulative } \\
\text { Percent }\end{array}$ \\
\hline \multirow[t]{5}{*}{ Valid } & $<50$ ribu per pembelian & 31 & 44.3 & 44.3 & 44.3 \\
\hline & $\begin{array}{l}50 \text { ribu - } 100 \text { ribu per } \\
\text { pembelian }\end{array}$ & 26 & 37.1 & 37.1 & 81.4 \\
\hline & $\begin{array}{l}100 \text { ribu - } 200 \text { ribu per } \\
\text { pembelian }\end{array}$ & 12 & 17.1 & 17.1 & 98.6 \\
\hline & $\begin{array}{l}200-300 \text { ribu per } \\
\text { pembelian }\end{array}$ & 1 & 1.4 & 1.4 & 100.0 \\
\hline & Total & 70 & 100.0 & 100.0 & \\
\hline
\end{tabular}

Sumber: Hasil Penelitian, 2020 (IBM SPSS Statistics 22)

\section{Analisis IFE dan EFE}

Analisis terhadap faktor internal dilakukan dalam upaya untuk melakukan identifikasi terhadap faktor kekuatan dan kelemahan yang berasal dari dalam usaha restoran. Hasil dari analisis ini akan digunakan untuk menyusun matriks Internal Factor Evaluation (IFE). Berdasarkan hasil 
pengolahan data dari pilihan faktor-faktor yang disuguhkan kepada 75 responden, diperoleh nilai rata-rata pendekatan terhadap status setiap faktor internal untuk diposisikan sehingga menjadi lima belas indikator kekuatan dan tujuh indikator kelemahan. Matriks IFE disusun berdasarkan nilai rata-rata bobot dari akumulasi jawaban responden konsumen, yang kemudian dilanjutkan dengan perhitungan nilai rata-rata rating dari akumulasi jawaban responden pengelola, untuk setiap butir faktor kekuatan dan butir faktor kelemahan, tercermin pada tabel 8 berikut.

Tabel 7. Matriks IFE dan EFE

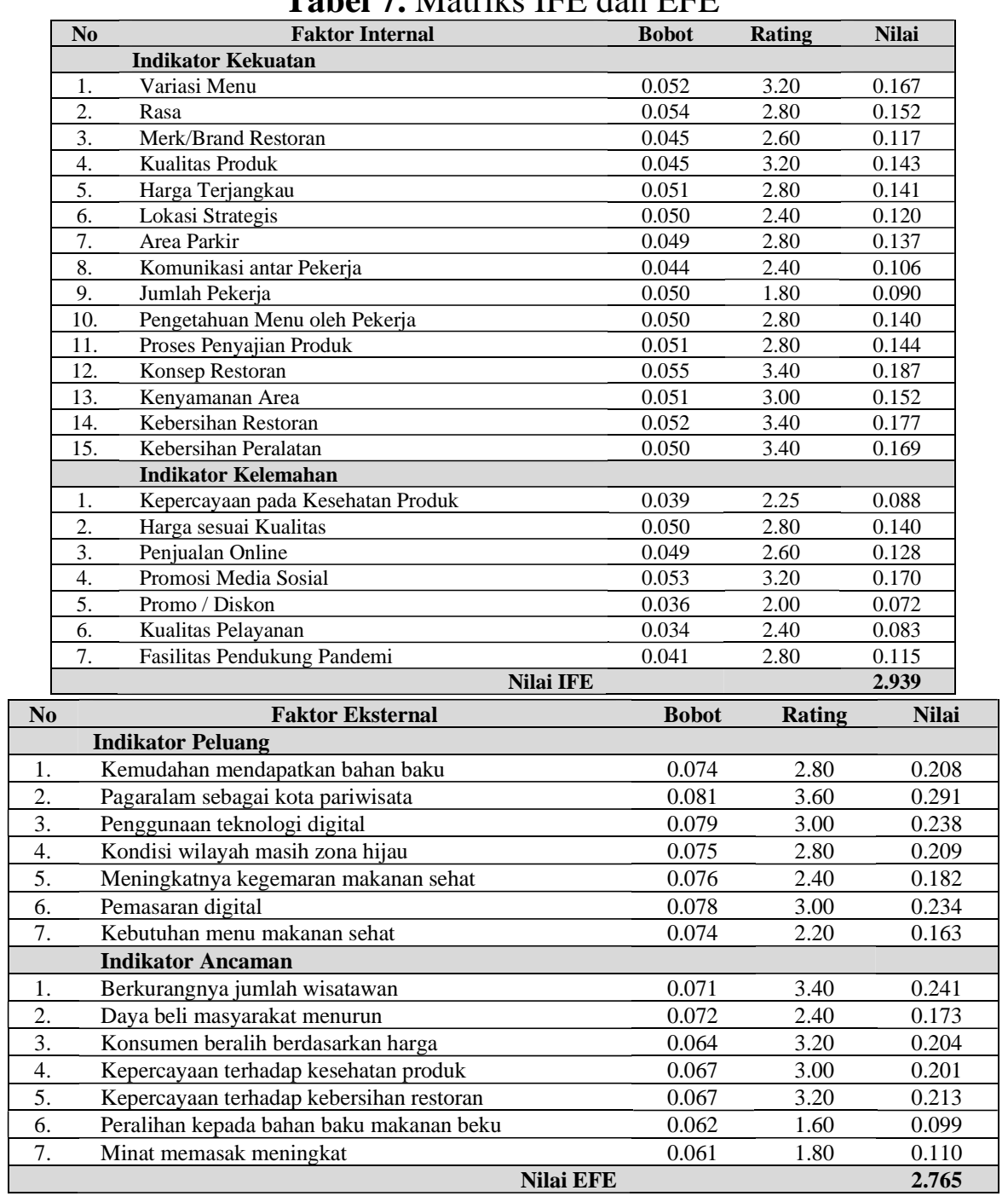

Sumber: Pengolahan Data Penelitian, 2020

Analisis terhadap faktor eksternal dilakukan dalam upaya untuk melakukan identifikasi terhadap faktor peluang dan ancaman yang berasal dari dalam usaha restoran. Hasil dari analisis ini akan digunakan untuk menyusun matriks External Factor Evaluation (EFE). Sama seperti pengolahan IFE, diperoleh nilai rata-rata pendekatan terhadap status setiap faktor eksternal untuk diposisikan sehingga menjadi tujuh indikator peluang maupun tujuh indikator ancaman. Matriks EFE juga disusun dengan pola sama dengan IFE, tercermin pada tabel berikut. 


\section{Analisis SWOT}

Analisis ini disusun berdasarkan asumsi bahwa suatu strategi yang efektif memaksimalkan kekuatan dan peluang serta meminimkan kelemahan dan ancaman suatu perusahaan melalui empat empat alternatif strategi yakni SO (Strengths, Opportunities), WO (Weakness, Opportunities), ST (Strengths, Threats), dan WT (Weakness, Threats) yang dapat dimplementasikan, mencakup:

1. Strategi SO, menggunakan indikator kekuatan dengan memanfaatkan peluang yang muncul, terdiri atas:

a. Membangun interaksi digital dengan target pasar untuk memperkenalkan identitas serta membuka ruang komunikasi digital dua arah. (S1,2,12-O2,3)

b. Membangun e-commerce melalui kolaborasi dengan platform online untuk mendekatkan diri dengan target pasar. (S1,3,12-O6,2)

2. Strategi WO, memperbaiki indikator kelemahan untuk mampu menggunakan indikator peluang yang tersedia, terdiri atas:

a. Membangun promosi melalui media sosial. (W4,5-O2,3,4)

b. Implementasi strategi pemasaran bundling. (W2,5-O6,1)

3. Strategi ST, mendayagunakan indikator kekuatan yang ada agar mampu mengatasi indikator ancaman yang muncul, terdiri atas:

a. Mengembangkan menu berorientasi pada konsumen lokal. (S1,4,5-T1,2,3)

b. Penerapan dan sertifikasi CHSE pada produk maupun lokasi usaha. $(\mathrm{S} 1,3,14,15-\mathrm{T} 4,5)$

4. Strategi WT, meminimalisir indikator kelemahan agar dapat mengatasi indikator ancaman, terdiri atas:

a. Fokus penjualan online bagi produk tertentu pada segmen pasar khusus. (W2,3,4-T1,2,3)

b. Informasi penerapan Prokes. melalui media sosial secara kontinu. (W1,7$\mathrm{T} 4,5)$

Setelah faktor-faktor kunci berhasil dipetakan melalui proses analisis matriks IFE yang memberikan informasi tentang faktor-faktor kekuatan dan kelemahan, matriks EFE yang memberikan informasi mengenai faktor-faktor peluang dan ancaman pada usaha restoran dalam menghadapi masa pandemik covid 19, maka selanjutnya dilakukan tahap pemaduan dengan menggunakan matriks Internal-External (IE) dan Matriks SWOT dan Quantitative Strategic Planning Matrix (QSPM).

\section{HASIL DAN PEMBAHASAN}

\section{Matriks IE}

Matriks Internal External disusun dengan menggunakan hasil evaluasi dari matriks IFE pada Tabel 8. dan matriks EFE pada Tabel 9. dimana sumbu horizontal adalah Total Weight Score dari matriks IFE sebesar 2,939 sedangkan sumbu vertikalnya adalah Total Weight Score dari matriks EFE sebesar 2,765 sehingga diperoleh diagram berikut. 

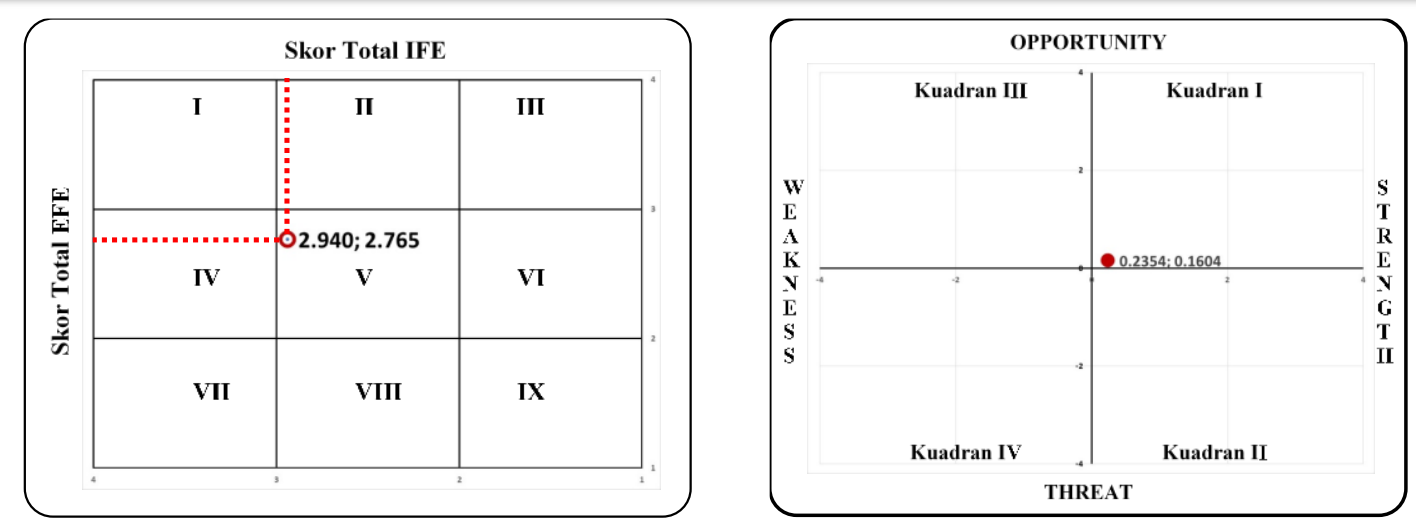

Gambar 1. Diagram Matriks IE dan Diagram Matriks SWOT Sumber: Pengolahan Data Penelitian, 2020

Diagram Matriks IE menunjukkan posisi usaha restoran di Kota Pagar Alam selama masa pandemi covid 19 berada pada kuadran lima. Dalam sel ini dipergunakan strategi Hold dan Maintain. Strategi yang umum digunakan pada situasi dan kondisi seperti ini yaitu strategi Market Penetration dan Product Development. Kedua jenis strategi ini adalah strategi intensif. Pelaksanaan strategi intensif terdiri dari strategi penetrasi pasar (market penetration) dan pengembangan produk (product development). Strategi intensif ini dalam implementasinya memerlukan usaha-usaha intensif untuk meningkatkan posisi persaingan perusahaan melalui produk-produk yang ada.

Pilihan pertama strategi penetrasi pasar merupakan suatu strategi yang dapat dilakukan dalam meningkatkan penjualan dari produk dimana pasar telah tersedia melalui usaha pemasaran yang agresif. Dalam hal ini, strategi penetrasi pasar berusaha mendorong usaha restoran agar lebih agresif melakukan pendekatan pada target pasarnya dengan menggunakan bantuan teknologi, sehingga tingkat penjualan dapat bertumbuh positif. Sedangkan pilihan kedua adalah strategi pengembangan produk merupakan aktivitas dimulai dari analisis persepsi dan peluang pasar kemudian diakhiri menjadi tahap produksi, penjualan dan pengiriman produk. Jenis strategi pengembangan produk pada periode ini, menurut peneliti tidak menjadi fokus utama disebabkan dua alasan utama yaitu pertama, dalam analisis butir faktor kekuatan, varian menu yang manjadi produk restoran cukup menjadi kekuatan signifikan dan kedua, strategi ini akan menyerap sumber daya seperti waktu dan tenaga yang cukup besar sehingga bertolak belakang dengan kondisi pandemic saat ini. Dengan begitu, strategi penetrasi pasar menjadi strategi utama yang dapat diimplementasikan sebagai bentuk output dari analisis terhadap Matriks IE. Strategi ini akan dikombinasikan dengan hasil dari alternatif strategi yang dihasilkan melalui analisis Matriks SWOT.

\section{Matriks SWOT}

Matriks SWOT disusun menyerupai dengan matriks IE, menggunakan olahan data bobot absolut dan rating yang sama dengan IFE dan EFE, tetapi matriks ini terkonsentrasi pada posisi objek penelitian (usaha restoran) dengan menghitung selisih dari setiap indikator pada faktor yang sama. Pada faktor internal, nilai indikator kekuatan didampingkan dengan nilai indikator kelemahan dan pada faktor eksternal, nilai indikator peluang didampingkan dengan nilai indikator ancaman. Hasil perhitungan faktor internal menghasilkan indeks kekuatan pada nilai 2,862 dan indeks kelemahan pada nilai 2,626 sehingga selisih indeks pada faktor internal diperoleh sebesar 0,235 poin sedangkan hasil perhitungan faktor eksternal menghasilkan indeks peluang pada nilai 2,839 dan indeks ancaman pada nilai 2,679 sehingga selisih indeks pada faktor eksternal diperoleh sebesar 0,160 poin, jika dalam bentuk diagram kartesius akan menghasilkan diagram berikut. 
Diagram Matriks SWOT menunjukkan posisi objek berada pada kuadran I dimana pada posisi kuadran ini, strategi agresif merupakan salah satu bentuk alternatif strategi yang disarankan, sama halnya dengan analisis menggunakan Matriks IE sebelumnya. Pada kuadran I, strategi yang dipergunakan adalah bentuk strategi SO. Dengan begitu, pilihan strategi penetrasi pasar sesuai Matriks IE akan dikombinasikan dengan dua alternatif strategi SO dari analisis SWOT, untuk dievaluasi pada tahapan berikutnya yaitu Matriks QSPM.

\section{Matriks QSPM}

Setelah dapat dipetakan alternatif strategi dengan menggunakan matriks IE dan matriks SWOT, selanjutnya untuk memilih alternatif strategi yang terbaik menggunakan Quantitative Strategic Planning Matrix (QSPM). Dalam tahap pengambilan keputusan melalui metode QSPM ini, dilakukan analisis informasi dari alternatif strategi yang dihasilkan melalui matriks IE dan matriks SWOT yang paling baik berdasarkan Total Attractive Score (TAS) terbesar.

Tabel 9. Matriks QSPM

\begin{tabular}{|c|c|c|c|c|c|c|}
\hline \multirow{2}{*}{ No } & \multirow{2}{*}{ Faktor Internal } & \multirow{2}{*}{ Bobot } & \multicolumn{2}{|c|}{ Strategi SO 1 } & \multicolumn{2}{|c|}{ Strategi SO 2} \\
\hline & & & AS & TAS & $\mathbf{A S}$ & TAS \\
\hline \multicolumn{7}{|c|}{ Indikator Kekuatan } \\
\hline 1. & Variasi Menu & 0.052 & 4 & 0.2088 & 4 & 0.2088 \\
\hline 2. & Rasa & 0.054 & 4 & 0.2176 & 3 & 0.1632 \\
\hline 3. & Merk/Brand Restoran & 0.045 & 4 & 0.1805 & 4 & 0.1805 \\
\hline 4. & Kualitas Produk & 0.045 & 4 & 0.1786 & 4 & 0.1786 \\
\hline 5. & Harga Terjangkau & 0.051 & 3 & 0.1515 & 4 & 0.2020 \\
\hline 6. & Lokasi Strategis & 0.050 & 3 & 0.1500 & 3 & 0.1500 \\
\hline 7. & Area Parkir & 0.049 & 2 & 0.0976 & 1 & 0.0488 \\
\hline 8. & Komunikasi antar Pekerja & 0.044 & 1 & 0.0442 & 1 & 0.0442 \\
\hline 9. & Jumlah Pekerja & 0.050 & 1 & 0.0500 & 1 & 0.0500 \\
\hline 10. & Pengetahuan Menu oleh Pekerja & 0.050 & 1 & 0.0500 & 1 & 0.0500 \\
\hline 11. & Proses Penyajian Produk & 0.051 & 1 & 0.0515 & 1 & 0.0515 \\
\hline 12. & Konsep Restoran & 0.055 & 4 & 0.2205 & 3 & 0.1654 \\
\hline 13. & Kenyamanan Area & 0.051 & 3 & 0.1522 & 2 & 0.1015 \\
\hline 14. & Kebersihan Restoran & 0.052 & 3 & 0.1559 & 2 & 0.1039 \\
\hline 15. & Kebersihan Peralatan & 0.050 & 3 & 0.1493 & 2 & 0.0995 \\
\hline \multicolumn{7}{|c|}{ Indikator Kelemahan } \\
\hline 1. & Kepercayaan pada Kesehatan Produk & 0.039 & 2 & 0.0786 & 3 & 0.1178 \\
\hline 2. & Harga sesuai Kualitas & 0.050 & 3 & 0.1500 & 4 & 0.2000 \\
\hline 3. & Penjualan Online & 0.049 & 3 & 0.1478 & 4 & 0.1971 \\
\hline 4. & Promosi Media Sosial & 0.053 & 4 & 0.2127 & 4 & 0.2127 \\
\hline 5. & Promo / Diskon & 0.036 & 3 & 0.1076 & 4 & 0.1434 \\
\hline 6. & Kualitas Pelayanan & 0.034 & 2 & 0.0688 & 3 & 0.1032 \\
\hline 7. & Fasilitas Pendukung Pandemi & 0.041 & 2 & 0.0825 & 1 & 0.0412 \\
\hline \multicolumn{7}{|c|}{ Indikator Peluang } \\
\hline 1. & Kemudahan mendapatkan bahan baku & 0.074 & 1 & 0.0742 & 1 & 0.0742 \\
\hline 2. & Pagaralam sebagai kota pariwisata & 0.081 & 3 & 0.2421 & 4 & 0.3228 \\
\hline 3. & Penggunaan teknologi digital & 0.079 & 4 & 0.3179 & 4 & 0.3179 \\
\hline 4. & Kondisi wilayah masih zona hijau & 0.075 & 3 & 0.2238 & 3 & 0.2238 \\
\hline 5. & Meningkatnya kegemaran makanan sehat & 0.076 & 1 & 0.0758 & 4 & 0.3033 \\
\hline 6. & Pemasaran digital & 0.078 & 4 & 0.3114 & 4 & 0.3114 \\
\hline 7. & Kebutuhan menu makanan sehat & 0.074 & 1 & 0.0742 & 3 & 0.2226 \\
\hline \multicolumn{7}{|c|}{ Indikator Ancaman } \\
\hline 1. & Berkurangnya jumlah wisatawan & 0.071 & 3 & 0.2129 & 1 & 0.0710 \\
\hline 2. & Daya beli masyarakat menurun & 0.072 & 1 & 0.0722 & 1 & 0.0722 \\
\hline 3. & Konsumen beralih berdasarkan harga & 0.064 & 3 & 0.1910 & 4 & 0.2547 \\
\hline 4. & Kepercayaan terhadap kesehatan produk & 0.067 & 2 & 0.1338 & 3 & 0.2007 \\
\hline 5. & Kepercayaan terhadap kebersihan restoran & 0.067 & 3 & 0.1995 & 1 & 0.0665 \\
\hline 6. & Peralihan kepada bahan baku makanan beku & 0.062 & 1 & 0.0616 & 1 & 0.0616 \\
\hline 7. & Minat memasak meningkat & 0.061 & 1 & 0.0612 & 1 & 0.0612 \\
\hline \multicolumn{3}{|c|}{ Kumulatif TAS: } & & 5.1581 & & 5.3777 \\
\hline
\end{tabular}

Sumber: Pengolahan Data Penelitian, 2020

Berdasarkan Tabel Matriks QSPM, strategi terbaik yang terpilih dapat dilakukan adalah strategi SO-2 dengan nilai TAS sebesar 5,3777. Strategi tersebut adalah membangun $e$ commerce melalui kolaborasi dengan platform online untuk mendekatkan diri dengan target 
pasar. Strategi ini secara eskplisit juga dapat digunakan dengan dukungan dari indikator kekuatan dengan bobot tertinggi yaitu variasi menu, rasa dan konsep restoran yang menjadi nilai lebih dari sudut pandang konsumen.

\section{KESIMPULAN DAN SARAN}

Berdasarkan hasil penelitian dan pembahasan, maka ditarik kesimpulan sebagai berikut:

1. Strategi terbaik yang dapat diimplementasikan adalah membangun e-commerce usaha restoran, cara paling sederhana adalah melakukan kolaborasi dengan platform online yang telah beroperasional terlebih dahulu. Strategi ini digunakan untuk memperkecil gap antara perusahaan dengan target pasar restoran.

2. Platform online dimaksud dapat dibagi menjadi tiga peluang pengembangan bisnis, berupa:

a. Pengunaan penyedia jasa layanan food and beverage yang dimiliki oleh Gojek seperti Go Food atau layanan Grab Food oleh Grab.

b. Pengembangan pola penjualan online melalui kolaborasi dengan marketplace seperti Shopee, Tokopedia dan lainnya.

c. Penjualan online secara langsung oleh restoran dengan menggunakan bantuan media sosial dan integrasi media pembayaran online seperti OVO, Dana dan lainnya.

3. Terdapat beberapa indikator kekuatan yang menjadi fokus konsumen dan merupakan nilai lebih restoran, dimana melalui plaform online dapat ditunjukkan citra positifnya kepada target pasar, dengan lebih intens. Indikator tersebut mencakup varian menu, rasa dan konsep yang dibangun oleh restoran. Tidak terbatas pada tiga indikator tersebut, indikator strength lainnya yang menjadi aspek perbaikan kedepannya dapat dipersiapkan peningkatan citranya. Bahan indikator weakness juga dapat ditransformasikan menjadi strength melalui pola tertentu tergantung kebutuhan perusahaan.

4. Strategi yang dipersiapkan ini juga sebagai salah satu bentuk ikut serta dalam penerapan protokol kesehatan selama masa pandemic covid 19. Selain itu, beralih mengikuti perkembangan teknologi akan menghasilkan big data bagi perusahaan yang dapat dianalisis dan digunakan bagi pengembangan usaha, produk maupun layanan.

Berdasarkan hasil penelitian, strategi yang terpilih, harus melakukan penyesuaian dengan dampak dari situasi pandemi covid 19 saat ini. Saran terhadap implementasi strategi terpilih, antara lain:

1. Demi mendukung strategi terpilih yaitu membangun e-commerce, maka perlu dilakukan pelatihan kepada pengelola restoran dalam dua ruang lingkup yaitu penggunaan teknologi digital dan pemahaman konsep pemasaran digital.

2. Tiga peluang pengembangan pada kesimpulan poin nomor dua, masing-masing memiliki kekhususuan tertentu seperti capaian dan proses bisnis berbeda. Salah satu kekhususan dimaksud misalnya, pada opsi a., maka akan ada kenaikan harga jual produk dikarenakan adanya syarat dan ketentuan berlaku, penambahan tersebut biasanya dibebankan pada konsumen. Sehingga, dikarenakan setiap usaha restoran memiliki pola pengelolaan yang unik, sehingga peluang pengembangan tersebut juga harus dipilih dan disesuaikan dengan pola tersebut agar dapat bergerak seiring pengelolaan usaha. 
3. Citra yang dibangun melalui e-commerce sebaiknya juga mempertimbangkan hasil penelitian karakteristik responden, sebab terjadi pergerakan identitas maupun perilaku konsumen sebagai bentuk dampak dari masa pandemi yang sedang dihadapi.

4. Big data sebagai salah satu output dari implementasi strategi menjadi basis penting, bukan hanya bagi keberlangsung usaha restoran di Pagar Alam tetapi juga dalam konteks lebih besar yaitu pengelolaan kepariwisataan yang komprehensif, sehingga untuk interval jangka panjang, harus dibangun komunikasi dan partisipasi aktif antar unit usaha dengan dinas pariwisata sebagai perwakilan pemerinta daerah Kota Pagar Alam.

\section{DAFTAR PUSTAKA}

Alamanda, D. T., Anggadwita, G., Raynaldi, M., Novani, S., \& Kijima, K. (2019). Designing Strategies using IFE, EFE, IE, and QSPM analysis: Digital Village Case. The Asian Journal of Technology Management, 12(1), 48-57.

Aprilius, A., Pono, M., Razak Munir, A., \& Manajemen Fakultas Ekonomi dan Bisnis, J. (2018). Strategi Pengembangan Usaha Restoran Menggunakan Analisis SWOT Dan QSPM (Quantitatif Strategic Planning) Di Restoran La Pizza Makassar.

Ejournal.Unmus.ac.id, IX(1), 53-61. http://ejournal.unmus.ac.id/index.php/ekosos/article/view/735

Astika, I. M. J., \& Suharyo, O. S. (2021). Internal and External Enviromental Strategy Analysis Using SWOT Matrix and QSPM. International Journal of Progressive Sciences and Technologies, 25(1). https://doi.org/10.52155/ijpsat.v25.1.2826

Badan Pusat Statistik Kota Pagar Alam. 2020. Kota Pagar Alam Dalam Angka 2020. Kota Pagar Alam: Badan Pusat Statistik

Badan Pusat Statistik Provinsi Sumatera Selatan. 2020. Provinsi Sumatera Selatan Dalam Angka 2020. Provinsi Sumatera Selatan: Badan Pusat Statistik

David, Fred R.2012. Manajemen Strategis Konsep. Jakarta: Salemba Empat.

Effendi, M., \& Santoso, I. (2016). Analisis Strategi Pemasaran Menggunakan Metode Quantitative Strategic Planning Matrix (QSPM) (Studi Kasus Di Restoran Waroeng Steak And Shake Cabang Soekarno Hatta Malang). Jurnal Teknologi Dan Manajemen Agroindustri, 5(1).

Kotler, Philip, Kevin Lane Keller. 2016. Marketing Management. 15th Edition. Pearson Education Inc.

Karo Karo, P. (2020). Analysis of Experiential Marketing Effect on Tourist Satisfaction Levels at The Tourist Restaurant in Belitung District. Tourism Scientific Journal, 5(2). https://doi.org/10.32659/tsj.v5i2.79

Mallick, S. K., Rudra, S., \& Samanta, R. (2020). Sustainable ecotourism development using SWOT and QSPM approach: A study on Rameswaram, Tamil Nadu. International Journal of Geoheritage and Parks.

Putri, N. E., Astuti, R., \& Putri, S. A. (2014). Perencanaan Strategi Pengembangan Restoran Menggunakan Analisis Swot Dan Metode QSPM (Quantitative Strategic Planning Matriks)(Studi Kasus Restoran Big Burger Malang). Industria: Jurnal Teknologi dan Manajemen Agroindustri, 3(2), 93-106.

Rangkuti, Freddy. 2009. Analisis SWOT Teknik Membedah Kasus Bisnis. Medan: USU Press Rosnawintang, R., Suwandi, S., \& Azisah, N. (2020). Analisis Daya Saing Dan Strategi Industri Makanan Dan Minuman Indonesia Di Era Masyarakat Ekonomi Asean. Jurnal Ekonomi Pembangunan (JEP) UHO, 5(2), 20-28. 
Rina Sari, P. K. L. T. (2019). Analisis Strategi Pengembangan UKM (Studi Kasus : Usaha Restoran Bakmi Ja di Kota Padang). JOSETA: Journal of Socio-Economics on Tropical Agriculture, 1(1). https://doi.org/10.25077/joseta.v1i1.9

S., Nur Asizah. (2015). Analisis Daya Saing Dan Strategi Industri Makanan Dan Minuman Indonesia Di Era Masyarakat Ekonomi Asean. In Jurnal Ekonomi Pembangunan (JEP) $U H O$ (Vol. 5, Issue 2).

Sukardono, E., Sarma, M., \& Sumantadinata, K. (2013). Strategi Pemasaran Restoran Pecel Lele Lela Cabang Pinangranti, Jakarta Timur. MANAJEMEN IKM: Jurnal Manajemen Pengembangan Industri Kecil Menengah, 8(2). https://doi.org/10.29244/mikm.8.2.170180

Tjiptono, Fandy. 2003. Total Quality Management. Yogyakarta: ANDI

Umar, Husein. 2010. Desain Penelitian Manajemen Strategik. Jakarta: Raja Grafindo

Wulandari, H. P., Khikmawati, E., \& Taminto, T. (2017). Penentuan Strategi Bersaing Menggunakan Analisis SWOT (Studi Kasus Pada PT. Keong Nusantara Abadi Natar Lampung Selatan). Jurnal Riset Akuntansi dan Manajemen Malahayati, 6(1), 11-17. 